\title{
MED17 wt Allele
}

National Cancer Institute

\section{Source}

National Cancer Institute. MED17 wt Allele. NCI Thesaurus. Code C52209.

Human MED17 wild-type allele is located in the vicinity of 11q14 and is approximately 29

$\mathrm{kb}$ in length. This allele, which encodes mediator of RNA polymerase II transcription subunit 17 protein, plays a role in the induction of transcription. 